\title{
EDITORIAL
}

\section{Transnational Environmental Law in a Transformed Environment}

First published online 21 May 2020

\section{INTRODUCTION}

In our previous editorial we commented on the tumultuous end of a decade and the environmental, social, and legal challenges that await. ${ }^{1}$ During the first four months of 2020 a global pandemic caused by the new coronavirus SARS-CoV-2, which can lead to the potentially deadly 'coronavirus disease 2019' (COVID-19), stormed onto this already daunting list of challenges. The urgency and all-encompassing nature of the effects of the pandemic has led it to overtake and complicate most other challenges in unpredictable and unprecedented ways.

Soon after the presumed start of the pandemic in the Chinese province of Wuhan in December 2019, the Chinese government took quarantine measures that many considered draconian and possible only in a centrally controlled country such as China. ${ }^{2} \mathrm{At}$ the time of writing, April 2020, similar measures have been adopted and political decisions have been taken all over the world in ways that long seemed unimaginable in peacetime. At the moment, Europe - especially Italy, Spain, and the United Kingdom (UK) - and the United States (US) seem to be at the centre of the pandemic. However, cases are increasingly reported in the Middle East, Africa, and India, raising profound concerns regarding the ability of developed and less developed healthcare systems to cope with the severe adverse health effects of the virus. Mortality rates, also in countries with well-equipped and well-funded public health systems, have been disconcertingly high and infection rates difficult to lower without very invasive measures.

The most common measures in place at the moment are various forms of lockdown', where freedom of movement is heavily curtailed, often allowing only those in 'essential' jobs - healthcare, some parts of the food industry, postal services - to

$\ddagger \quad$ The original version of this article was published with errors. A notice detailing the errors has been published and the errors corrected in the online PDF and HTML copies.

1 T.F.M. Etty, V. Heyvaert, et al., 'The End of a Decade and the Dawn of a Climate Resistance' (2020) 9(1) Transnational Environmental Law, pp. 1-9.

2 K. Kupferschmidt \& J. Cohen, 'Can China's COVID-19 Strategy Work Elsewhere?' (2020) 367(6482) Science, pp. 1061-2; L. Kuo, “'Liberation”, as Wuhan's Coronavirus Lockdown Ends after 76 Days', The Guardian, 7 Apr. 2020, available at: https:/www.theguardian.com/world/2020/apr/07/liberationas-wuhans-coronavirus-lockdown-ends-after-76-days. 
work outside the home, and restricting other activities outside the home to sporadic exercise activities and essential activities such as shopping for groceries while maintaining physical distance from others. The estimated number of people currently under some form of lockdown is around 2.6 billion, ${ }^{3}$ accounting for more than one third of the 7.58 billion world population. A large part of this number is made up by the population of India (1.3 billion people) who were placed under strict lockdown on 25 March 2020. This has caused widescale human suffering for many of the migrant workers within India who were forced to undertake dangerous, and illegal, ${ }^{4}$ journeys on foot back to their villages, where they hoped to have a better chance of access to food and other essentials. Some countries, such as New Zealand and Australia, appear to have been able to 'flatten the curve' by taking strict measures at an early stage of detection, ${ }^{5}$ while other countries, such as Sweden, have adopted much less restrictive measures, potentially allowing the disease to run its course. It is not yet clear which of these methods will be most successful in limiting the mortality of this disease in the long run.

Many of the profound economic and social impacts of the pandemic, and our attempts to limit its spread, have been immediate, with many economies coming to a virtual standstill overnight. ${ }^{6}$ Unemployment has soared to record heights in the US and the price of crude oil has dropped below zero for the first time in history. ${ }^{7}$ These effects are expected to be long-lasting and profound, with many industries doubting whether recovery is possible at all. ${ }^{8}$ More systemic challenges, such as an economic depression, seem likely. ${ }^{9}$ Worryingly, basic necessities - including food - may not be available to a large share of the world population in the near future without carefully planned, yet urgent, action. ${ }^{10}$

3 M. Jankowicz, 'More People Are Now in “Lockdown” than Were Alive During World War II', Business Insider, 25 Mar. 2020, available at: https://www.businessinsider.com/more-people-under-lockdownthan-alive-during-world-war-ii-2020-3.

4 D.K. Pandey, 'Coronavirus: Migrant Workers To Be Stopped, Quarantined at Borders, Says Centre', The Hindu, 29 Mar. 2020, available at: https://www.thehindu.com/news/national/coronavirus-centrewarns-lockdown-violators-of-14-day-quarantine/article31198038.ece.

5 N. Wilson, L.T. Barnard \& M. Baker, 'Rationale for Border Control Interventions and Options to Prevent or Delay the Arrival of Covid-19 in New Zealand: Final Commissioned Report for the New Zealand Ministry of Health', University of Otago, Wellington (New Zealand), 6 Mar. 2020; A. Fifield, 'New Zealand Is Not Just Flattening the Curve. It's Squashing It', The Washington Post, 7 Apr. 2020, available at: https://www.washingtonpost.com/world/asia_pacific/new-zealand-isnt-just-flattening-the-curve-itssquashing-it/2020/04/07/6cab3a4a-7822-11ea-a311-adb1344719a9_story.html. A. Klein, 'Australia Seems To Be Keeping a Lid on Covid-19: How Is It Doing It?', The New Scientist, 8 Apr. 2020, available at: https://www.newscientist.com/article/2240226-australia-seems-to-be-keeping-a-lid-on-covid-19-how-isit-doing-it/\#ixzz6LQA9UEfh.

6 L. Jones, D. Palumbo \& D. Brown, 'Coronavirus: A Visual Guide to the Economic Impact', BBC News, 27 Apr. 2020, available at: https://www.bbc.com/news/business-51706225.

7 J. Ambrose, 'Over a Barrel: How Oil Prices Dropped Below Zero', The Guardian, 20 Apr. 2020, available at: https://www.theguardian.com/business/2020/apr/20/over-a-barrel-how-oil-prices-dropped-below-zero.

8 The aviation industry is facing profound difficulties: see, e.g., S. Saeed \& T. Snyder, 'What Happens to Airlines after the Coronavirus Crisis Ends?', Politico, 9 Apr. 2020, available at: https://www.politico. eu/article/what-happens-to-airlines-after-the-coronavirus-crisis-ends.

9 J. Bluedorn, G. Gopinath \& D. Sandri, 'An Early Review of the Economic Impact of the Pandemic in 5 Charts', IMFBlog, 6 Apr. 2020, available at: https://blogs.imf.org/2020/04/06/an-early-view-of-the-economic-impact-of-the-pandemic-in-5-charts.

10 The World Food Programme estimates that the pandemic could lead to a doubling of the number of people facing food insecurity within the next year: see Food Security Information Network, 2020 Global Report on Food Crises: Joint Analysis for Better Decisions (Global Network Against Food Crises, 
Notwithstanding ongoing uncertainty regarding the scale and timeline of the current pandemic, the world that will emerge from this globally disruptive event inevitably will look different from the one we knew before. For some, this is a cause for optimism: perhaps the current social and economic turmoil can be a catalyst for a more equitable and sustainable society. ${ }^{11}$ Others fear that during the period before a vaccine is found, existing inequalities will be increasingly exacerbated and life 'as usual' will continue, or resume, only for the lucky few. ${ }^{12}$

For environmental scholars, particularly those with a deep interest in transnational environmental law, this 'new normal' poses many pressing questions. What will be the importance of our work given these changed conditions? What will change and which changes are relevant? The answers to these and many more questions depend on the short- and long-term impacts of the pandemic, our response to it and its aftermath, on the environment itself, and on the actors and legal frameworks that regulate our environment. Moreover, it is worth noting that the relationship between our natural and social environment has never been more important, nor subject to such intense scrutiny.

The outbreak of the pandemic has been linked to our treatment of nature and animals in important ways, raising questions of the sustainability of our current food system and treatment of animals. ${ }^{13}$ The measures currently in place to fight the pandemic, while very costly in myriad ways, have led to a meaningful drop in pollution all over the world, allowing countries (temporarily) to achieve environmental goals that were thought overly ambitious in light of the economic compromises they required. ${ }^{14}$ The heavy restrictions on travel and other activities may also trigger a shift in values, ${ }^{15}$ making it easier to imagine an economy that incorporates more work from home and less professional travel. The unequal way in which the pandemic affects population groups, especially with regard to age and gender, may also lead to a shift in demographics with far-reaching consequences. ${ }^{16}$ Finally, while there are positive environmental effects, it is

2020), available at: https:/docs.wfp.org/api/documents/WFP-0000114546/download/?_ga=2. $163564732.1600278190 .1587546637-1713667980.1587546637$.

11 A petition created by an interdisciplinary group of Dutch academics had been signed 3,538 times by 30 Apr. 2020: see Voetafdruk, 'Laat Nederland Eerlijker en Duurzamer uit de Coronacrisis Komen', Petities.nl, Apr. 2020, available at: https://petities.nl/petitions/laat-nederland-eerlijker-en-duurzameruit-de-coronacrisis-komen?locale=nl.

12 O. Jones, 'Coronavirus Is Not Some Great Leveller: It Is Exacerbating Inequality Right Now', The Guardian, 9 Apr. 2020, available at: https://www.theguardian.com/commentisfree/2020/apr/09/coronavirus-inequality-managers-zoom-cleaners-offices.

13 N. de Sadeleer \& J. Godfroid, 'The Story Behind COVID-19: Animal Diseases at the Crossroads of Wildlife, Livestock and Human Health' (2020) European Journal of Risk Regulation (forthcoming), available at: doi:10.1017/err.2020.45.

14 J. Watts \& N. Kommendo, 'Coronavirus Pandemic Leading to Huge Drop in Air Pollution', The Guardian, 23 Mar. 2020, available at: https://www.theguardian.com/environment/2020/mar/23/coronavirus-pandemic-leading-to-huge-drop-in-air-pollution; S. Evans, 'Analysis: Coronavirus Set To Cause Largest Ever Annual Fall in $\mathrm{CO}_{2}$ Emissions', Carbon Brief, 9 Apr. 2020, available at: https://www.carbonbrief.org/analysis-coronavirus-set-to-cause-largest-ever-annual-fall-in-co2-emissions.

15 A. Rowell, 'COVID-19 and Environmental Law', 22 Apr. 2020, available at SSRN: https://ssrn.com/ abstract $=3582879$.

16 J. Xie, Z. Tong \& X. Guan, 'Clinical Characteristics of Patients Who Died of Coronavirus Disease 2019 in China' (2020) 3(4) Jama Netw Open, pp. 1-4, at 1; S. Richardson et al., 'Presenting Characteristics, 
unclear which of these will last: the need to maintain social distancing for a long period of time could also lead to an increase in car use and decrease in public transport use. Moreover, the vast amount of resources currently spent on combating this pandemic cannot be used for fighting other crises, such as climate change. At the European level, many legislative and policy plans under the European Union (EU) 'Green Deal' have already been reported to be delayed until $2021 .^{17}$

These pressing social issues will have a major impact on environmental scholarship. Moreover, the coronavirus crisis has profound direct effects on the academic community itself, including effects on our ability to engage in (certain types of) research, ${ }^{18}$ the funding that will be available, ${ }^{19}$ and the form that teaching will take in the future. ${ }^{20}$ The many questions that emerge, and their answers, undoubtedly will be heavily debated in this journal and the academic community at large, fostering a discussion which we hope will continue to be diverse in terms of geography, gender, and stage of academic career.

The contributions to the current issue naturally predate the start of the pandemic. Nevertheless, many of the themes of these articles relate directly to some of the questions that we will face in the coming years. In the first two articles, Gor Samvel ${ }^{21}$ and Iyan Offor ${ }^{22}$ underline the importance of verifying scholarly assumptions on the effects of environmental law through empirical research. Contributions by Aleksandra Čavoški and Jaye Ellis highlight another interaction which has been central to environmental legal scholarship and practice, and will become even more so: the relationship between science and law - including the different processes and institutions involved in forging this relationship, ${ }^{23}$ and the values which underpin it. ${ }^{24}$ The final two articles in this volume address developments in environmental litigation, specifically climate change litigation. In both articles the role of private actors in climate litigation is highlighted: Samvel Varvastian and Felicity Kalunga consider the specific

Comorbidities, and Outcomes among 5700 Patients Hospitalized with COVID-19 in the New York City Area' (2020) JAMA, p. 1, available at: https://www.ncbi.nlm.nih.gov/pubmed?term=32320003.

17 See F. Simon, 'Leaked: Full List of Delayed European Green Deal Initiatives', EURACTIV, 16 Apr. 2020, available at: https:/www.euractiv.com/section/energy-environment/news/leaked-full-list-of-delayedeuropean-green-deal-initiatives.

18 See, e.g., A. Minello, 'The Pandemic and the Female Academic', Nature, 17 Apr. 2020, available at: https://www.nature.com/articles/d41586-020-01135-9; L. Taylor, 'Ten Work-Life Balance Tips for Researchers Based at Home during the Pandemic', Nature, 8 Apr. 2020, available at: https://www.nature. com/articles/d41586-020-01059-4.

19 The EU has already changed the deadlines of all research programmes: see European Commission, 'Funding and Tender Opportunities', European Research Area (ERA) Corona Platform, available at: https://ec.europa.eu/info/funding-tenders/opportunities/portal/screen/covid-19.

20 See G. Tam \& D. El-Azar, '3 Ways the Coronavirus Could Reshape Education', World Economic Forum, 13 Mar. 2020, available at: https://www.weforum.org/agenda/2020/03/3-ways-coronavirus-is-reshaping-education-and-what-changes-might-be-here-to-stay.

21 G. Samvel, 'Non-Judicial, Advisory, Yet Impactful? The Aarhus Convention Compliance Committee as a Gateway to Environmental Justice' (2020) 9(2) Transnational Environmental Law, pp. 211-38.

22 I. Offor, 'Animals and the Impact of Trade Law and Policy: A Global Animal Law Question' (2020) 9(2) Transnational Environmental Law, pp. 239-62.

23 A. Čavoški, 'Science and Law in Environmental Law and Policy: The Case of the European Commission' (2020) 9(2) Transnational Environmental Law, pp. 263-95.

24 J. Ellis, 'Calculative Practices in International Environmental Governance: In (Partial) Defence of Indicators' (2020) 9(2) Transnational Environmental Law, pp. 297-321. 
challenge of holding transnational corporate entities to account for environmental damage, ${ }^{25}$ whereas Kim Bouwer's work uses metaphor in order to craft a critical perspective on the purported payoffs and limitations of large-scale private law climate litigation. ${ }^{26}$ Combined, these thought-provoking pieces provide critical reflections on how we can future-proof both environmental law itself and the scholarship that studies it.

\section{2. 'A LITTLE KNOWLEDGE IS A DANGEROUS THING': THE ROLE OF EMPIRICS IN ENVIRONMENTAL LAW}

Effective environmental law needs to be able to affect human behaviour. This is true for all areas of law but sometimes this is more challenging to achieve, and measure, in environmental law, as the impacts of human behaviour on the environment are often geographically or temporally distant, and the relationship between behaviour and impact can be highly complex. ${ }^{27}$ Moreover, legal scholars are not always best placed to determine the effect of the law. If we infer the effect of law from the content of court rulings, we have a clear advantage, but if we look at alternative indicators, such as levels of pollution or changes in people's values and attitudes, other disciplines arguably are better equipped to collect and process the necessary information in a reliable way. Without the crucial feedback loops between the law and its real-life effects, we run the risk of basing our assumptions of 'what works' on untested theory, intuitions, and anecdote, thereby potentially reducing the effectiveness of environmental law and squandering precious opportunities for improvement. For example, insights from psychology indicate that many established climate communication strategies - emphasizing the high stakes of an issue like climate, linking climate stakes to people's personal interests, or cautioning people that they may actually hurt others through their behaviour - risk reducing people's willingness to confront the problem, because they feel they need cognitively and emotionally to minimize the (perceived) harm. ${ }^{28}$ This would suggest that people's inaction can be a result of understanding the urgency of the situation rather than of ignorance, and that arguably our communication strategies should be changed accordingly.

The need for empirical research in environmental legal scholarship is profound and pressing in all areas of environmental law. Gor Samvel's empirical work on the effects of the Compliance Committee of the Aarhus Convention on Access to Information, Public Participation in Decision-Making and Access to Justice in Environmental Matters (Aarhus Convention) ${ }^{29}$ is an important contribution to identifying the

25 S. Varvastian \& F. Kalunga, 'Transnational Corporate Liability for Environmental Damage and Climate Change: Reassessing Access to Justice after Vedanta v. Lungowe' (2020) 9(2) Transnational Environmental Law, pp. 323-45.

26 K. Bouwer, 'Lessons from a Distorted Metaphor: The Holy Grail of Climate Litigation' (2020) 9(2) Transnational Environmental Law, pp. 347-78.

27 See J. van Zeben \& A. Rowell, A Guide to EU Environmental Law (University of California Press, forthcoming 2020).

28 A. Rowell \& K. Bilz, The Psychology of Environmental Law (New York University Press, forthcoming 2021).

29 Aarhus (Denmark), 25 June 1998, in force 30 Oct. 2001, available at: https://www.unece.org/env/pp/ treatytext.html. 
elements that help in making environmental law effective. The work of the Aarhus Convention Compliance Committee has traditionally been characterized as nonjudicial and non-binding, but its rulings are increasingly considered as binding, authoritative interpretations of the Convention. ${ }^{30}$ The assumption tested in Samvel's piece is whether the binding effect of rulings, such as those made by the Compliance Committee, depends on their legal status and effect. For the Compliance Committee, the data shows that the substance of the rulings, rather than their binding effect, determines parties' actions. ${ }^{31}$ This underlines the importance of extra-legal factors in the decision making of states and, more pointedly, that judicialization may not be necessary in order to achieve compliance in transnational environmental law.

Iyan Offor provides empirical insights relating to a different area of environmental law, namely animal welfare and justice, in order to test assumptions regarding the impact of trade on animal welfare. Offor's empirical findings reveal that there are more questions than answers: currently available data about trade in animals does not include the information that would be needed to answer questions about animal welfare. ${ }^{32}$ Offor identifies four main ways in which trade has an impact on animal welfare: firstly, through open markets that allow low-welfare imports, which in turn give rise to low animal-welfare havens and create a potential chilling effect or even a race to the bottom, as well as pressure on states to refrain from trade restrictions on the basis of animal welfare. Finally, the absence of labelling requirements allows this negative cycle to continue as a result of lack of consumer awareness. ${ }^{33}$ Importantly, existing data fails to capture the true scope and scale of animal suffering caused by trade, as the developing field of global animal law is 'disproportionately impacted upon' by the normative underpinnings of trade law and policy. ${ }^{34}$ This 'bias' is confirmed by the bias in the data. Indeed, Offor's search for quantitative data shows us that the very use of certain types of data can reflect an ideological position on the topic at hand (the relative weight of animal welfare and trade objectives). ${ }^{35}$ This demonstrates that the presence or absence of data is not only important to explicate, confirm, or reassess relationships which we believe to exist, but also to highlight relationships of which we are not yet aware, or which remain unexplored. Such blindspots can inform legislative action as powerfully as full information on certain processes. The use of information, and the ability to access it, is also central to two other contributions to this volume, which discuss the relationships between law, science, and scientific information.

30 Samvel, n. 21 above, p. 212.

31 Ibid., p. 232.

32 Offor, n. 22 above, p. 240.

33 Introduced briefly in Offor, ibid., p. 248 and discussed in detail in Offor, ibid., pp. 248-59.

34 Ibid., p. 260.

35 Ibid., p. 240 ('This section uses empirical research to reveal the continued dominance of trade in European policymaking and its negative impact on animal welfare'). 


\section{3. 'KNOWLEDGE IS POWER': SCIENCE IN LAW}

The complexity of environmental processes poses significant challenges for environmental regulators, both in terms of 'getting the law right' and in terms of needing to allow for sufficient flexibility to enable law to respond to new scientific insights two objectives which are difficult to achieve in isolation and fiendishly hard to accomplish in combination. Aleksandra Čavoški's contribution shows how the European Commission fosters the 'co-production' of science and law through institutional processes and instruments that facilitate discourses between scientists and lawyers. ${ }^{36}$ Highlighting another important application for empirical research in environmental legal scholarship, Čavoški's article deploys newly collected data on the Commission's legislative process in order to show how scientific knowledge is integrated into EU law and policy. ${ }^{37}$ She rightly observes that the role of science and scientific information in law is increasingly important and debated, ${ }^{38}$ which only increases the need to understand these practices empirically. Moreover, by incorporating Jasanoff's theory of co-production in her analysis - which underscores the interdependence between science and law as social processes - Čavoški convincingly illustrates how the European Commission has acted as a conduit for co-production and thereby acts as a nexus between science and law in environmental policy. ${ }^{39}$ Relating back to our earlier observations about the nature of the empirical information that environmental law needs and the role of legal scholars in obtaining this information, it is worth mentioning Čavoški's emphasis on the difference between the work of political scientists on the functioning of the European Commission on the one hand, and available, or desirable, legal empirical work on the other. ${ }^{40}$ While legal scholars may lack certain methodological skills, their understanding of the legal process allows for insights that are typically lacking in the work of political scientists. This leads to different types of information collected and different insights gained.

Čavoški concludes by emphasizing the inherent value judgments involved in the incorporation and presentation of scientific information in policy and legislative processes. ${ }^{41}$ The contribution by Jaye Ellis relates closely to this observation and the more general proposition that scientific knowledge is a prerequisite for making effective and 'good' environmental policy. ${ }^{42}$ Specifically, Ellis' thoughtful piece reflects on the critiques of the increasingly central role of data within sustainability governance through the use of goals and indicators, often as an alternative to law. By presenting a more nuanced view of the scientific process, and the scientists, behind increasingly popular calculative practices in environmental regulation, Ellis considers whether the critiques of reliance on indicators are well-founded, or instead are overly beholden to

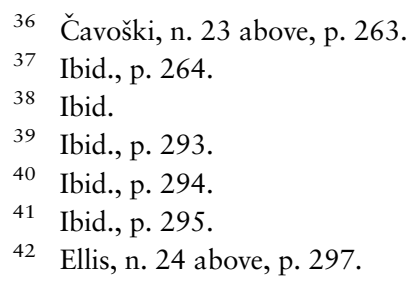


stereotypical representations of science and its processes. ${ }^{43}$ Her conclusion is that goals and indicators can be potentially valuable 'boundary objects' which may help to create a shared understanding among different fields, including politics, law, economics, and science - and thereby facilitate communication and collaboration between people working on sustainability governance in these respective fields. However, much of this depends on the weight given to goals and indictors and their interpretation. When used as a means to replace normative dimensions of difficult sustainability problems with technical information, something important is lost in international environmental governance. ${ }^{44}$

The common challenge identified by Čavoški and Ellis - how to use the wealth of scientific data currently available to us to create better law and policy - extends to the regulatory challenge posed by the coronavirus pandemic: never in history has there been a time in which we have learned more about a virus in such a short period of time, or have been better placed to rapidly construct a vaccine to fight it. $^{45}$ Nevertheless, the science and statistics of this pandemic alone are not sufficient to create 'good' law to fight it. ${ }^{46}$ Already, legal scholars are questioning the legality and legitimacy of some of the security measures taken by governments in light of their privacy and freedom of movement impacts. ${ }^{47}$ When the dust has settled, it is to be expected that many governments, and companies, will be scrutinized for the actions they are currently taking to combat the pandemic. The complex, interconnected global society in which these events are taking place, and the common good that a pandemic-free world represents, present important parallels between this future litigation and the environmental litigation of today. ${ }^{48}$

43 Ibid., p. 299.

44 Ibid., pp. 320-1.

45 For an overview of the research being undertaken, see World Health Organization, 'Global Research on Coronavirus Disease (COVID-19)', available at: https://www.who.int/emergencies/diseases/novel-coronavirus-2019/global-research-on-novel-coronavirus-2019-ncov. For legal considerations on this topic, see M. Morvillo, 'I Just Can't Get Enough (of Experts): The Numbers of COVID-19 and the Need for a European Approach to Testing' (2020) European Journal of Risk Regulation (forthcoming), available at: https://doi.org/10.1017/err.2020.41.

46 For the impact of risk perception on COVID-19 policy making, see S. Chakraborty, 'How Risk Perceptions, not Evidence, Have Driven Harmful Policies on COVID-19' (2020) European Journal of Risk Regulation (forthcoming), available at: https://doi.org/10.1017/err.2020.37.

47 See, inter alia, M. Longobardo, 'The Duties of Occupying Powers in Relation to the Fight Against COVID-19', EJIL:Talk!, 8 Apr. 2020, available at: https://ssrn.com/abstract=3571342; R. Vassileva, 'Bulgaria: COVID-19 as an Excuse to Solidify Autocracy?', Verfassungsblog, 10 Apr. 2020, available at: https://verfassungsblog.de/bulgaria-covid-19-as-an-excuse-to-solidify-autocracy; J. Kukavica, '(Rule of) Law in the Time of Covid-19: Warnings from Slovenia', Verfassungsblog, 25 Mar. 2020, available at: https://verfassungsblog.de/rule-of-law-in-the-time-of-covid-19-warnings-from-slovenia; S. Grund, 'The Legality of the European Central Bank's Pandemic Emergency Purchase Programme', Delors Institute Policy Brief Draft, 25 Mar. 2020, available at: https://ssrn.com/abstract=3558677; A. Spadaro, 'COVID-19: Testing the Limits of Human Rights' (2020) European Journal of Risk Regulation (forthcoming), available at: https://doi.org/10.1017/err.2020.27.

48 Naturally, there are also meaningful differences, such as the fact that environmental impacts tend to take longer to materialize, especially in the case of climate change: see, e.g., N. Dolsak \& A. Prakash, 'Here's Why Coronavirus and Climate Change Are Different Sorts of Policy Problems', Forbes, 15 Mar. 2020, available at: https://www.forbes.com/sites/prakashdolsak/2020/03/15/heres-why-coronavirus-and-climate-change-are-different-sorts-of-policy-problems. 


\section{VICTORY AND DEFEAT IN ENVIRONMENTAL LITIGATION}

Environmental litigation speaks to the lawyerly imagination, particularly in the case of widespread and severe environmental damage which is difficult to litigate because of causation and standing hurdles. ${ }^{49}$ The revolutionary judgment in the Dutch Urgenda case resulted in an order for the government to reduce carbon dioxide $\left(\mathrm{CO}_{2}\right)$ emissions by 15 megatonnes in $2020,{ }^{50}$ which is being implemented through a policy package involving additional scale-back of coal-power stations, reduced cattle and pig herds, and increased subsidies to home owners. ${ }^{51}$ Urgenda has also led to a wealth of scholarly debate on the role of litigation in addressing environmental problems such as climate change. ${ }^{52}$ In this ongoing debate the contributions by Kim Bouwer, and Samvel Varvastian and Felicity Kalunga, draw our attention to important developments, especially with regard to the role of private actors.

Private actors play a crucial role in transnational environmental law in the creation, shaping, and maintaining of rules. ${ }^{53}$ Many private pathways have opened up alongside traditional governmental strategies for legislation and enforcement, exactly because established avenues tend to constrain private actor involvement. ${ }^{54}$ Through a discussion of the UK Supreme Court case of Vedanta v. Lungowe, Samvel Varvastian and Felicity Kalunga show important progress in the availability of judicial opportunities for private actors to hold transnational corporations to account for their environmental behaviour. ${ }^{55}$ Vedanta v. Lungowe concerns a subsidiary of an English parent company which operates in Zambia and which has caused extensive environmental damage

49 For an historic overview of climate litigation in the US Supreme Court, see R. Lazarus, The Rule of Five: Making Climate History at the Supreme Court (Harvard University Press, 2020).

50 Court of Appeal of The Hague, 20 Dec. 2019, Stichting Urgenda v. Staat der Nederlanden, ECLI:NL: GHDHA:2018:2591 (Urgenda, The Hague Court of Appeal), available at: https://uitspraken. rechtspraak.nl/inziendocument?id=ECLI:NL:HR:2019:2006.

51 See also J. Watts, 'Dutch Officials Reveal Measures to Cut Emissions after Court Ruling', The Guardian, 24 Apr. 2020, available at: https://www.theguardian.com/world/2020/apr/24/dutch-officials-reveal-measures-to-cut-emissions-after-court-ruling; Ministerie Economische Zaken en Klimaat, 'Kamerbrief over Urgenda-vonnis', Rijksoverheid, 24 Apr. 2020, available at: https://www.rijksoverheid.nl/documenten/ kamerstukken/2020/04/24/kamerbrief-over-uitvoering-urgenda-vonnis.

L. Burgers, 'Should Judges Make Climate Change Law?’ (2020) 9(1) Transnational Environmental Law, pp. 55-75; J. van Zeben, 'Establishing a Governmental Duty of Care for Climate Change Mitigation: Will Urgenda Turn the Tide?' (2015) 4(2) Transnational Environmental Law, pp. 339-57; B. Mayer, 'The State of the Netherlands v. Urgenda Foundation: Ruling of the Court of Appeal of The Hague (9 October 2018)' (2019) 8(1) Transnational Environmental Law, pp. 167-92; K.J. de Graaf \& J.H. Jans, 'The Urgenda Decision: Netherlands Liable for Role in Causing Dangerous Global Climate Change' (2015) 27(3) Journal of Environmental Law, pp. 517-27; J. Verschuuren, 'The State of the Netherlands $v$ Urgenda Foundation: The Hague Court of Appeal Upholds Judgment Requiring the Netherlands to Further Reduce its Greenhouse Gas Emissions' (2019) 28(1) Review of European, Comparative \& International Environmental Law, pp. 94-8.

53 V. Heyvaert, Transnational Environmental Regulation and Governance: Purpose, Strategies and Principles (Cambridge University Press, 2018).

54 K. Raustiala, 'The "Participatory Revolution" in International Environmental Law' (1997) 21(2) Harvard Environmental Law Review, pp. 537-86; D.B. Hollis, 'Private Actors in Public International Law: Amicus Curiae and the Case for the Retention of State Sovereignty' (2002) 25(2) Boston College International and Comparative Law Review, pp. 235-55.

55 Varvastian \& Kalunga, n. 25 above, p. 323. 
through copper mining. ${ }^{56}$ The subsidiary as well as the English parent company were sued in the English courts by 1,862 Zambian citizens. The action was based on Zambian law and the common law of negligence, nuisance, and trespass. ${ }^{57}$ Unsurprisingly, the companies challenged the jurisdiction of the English courts. ${ }^{58}$ Much less expectedly, this claim was rejected, in large part on the basis that the claimants were unlikely to obtain substantial justice in Zambia. ${ }^{59}$ The Court held that the English parent company owes a duty of care to foreign claimants affected by the operations of its foreign subsidiaries, which then gives rise to jurisdiction for the English courts.

Varvastian and Kalunga explore the possible impact of the court ruling, particularly on transnational corporate liability litigation and climate change litigation. As a procedural matter, Vedanta appears to confirm that a case could be brought successfully in the home state of the parent company if there are concerns regarding the financial ability of the subsidiary to cover resulting damages awards, ${ }^{60}$ lack of expertise of the host state courts, ${ }^{61}$ or concerns regarding effective enforcement of a judgment. ${ }^{62}$ Assuming that these cases are admitted, there are specific reasons why the ruling in Vedanta (and similar cases) presents opportunities for transnational corporate liability and climate change litigation. With regard to the former, Varvastian and Kalunga highlight the ubiquity of multinational corporations in the legal landscape and the importance of being able to hold them to account. Here, Vedanta importantly confirms the presence of a duty of care of English parent companies. ${ }^{63}$ Whether this may be enough to overcome other obstacles, particularly those that have developed through case law related to the US Alien Tort Statute, ${ }^{64}$ is, however, doubtful. ${ }^{65}$ In the area of climate change litigation there may be more cause for optimism. Allowing a case against the parent company in the home state for environmental harm caused by a subsidiary could make it easier to overcome the causal link problem that tends to affect climate change cases: the cumulative effect of the greenhouse gas emissions of both the parent and subsidiary companies is more likely to lead to a viable case than when looking at these emissions in isolation. ${ }^{66}$

Their sobering conclusion is that the potentially positive effects of the case - including the possibility of bringing an action in the jurisdiction of the parent company - are

\footnotetext{
56 Ibid., p. 325.

57 Ibid., p. 326.

58 Ibid., pp. 326-7.

59 Ibid., p. 329.

60 Ibid., p. 329-30.

61 Ibid.

62 Ibid., p. 332.

63 Ibid., p. 335.

6428 U.S.C. $\$ 1350$.

65 Ibid., pp. 335-6.

66 Ibid., p. 342.
} 
promising but could ultimately be countered by distancing of the parent company and subsidiary in order to shield the former from liability. ${ }^{67}$ In such a situation the reasons for allowing the case to proceed in the UK - namely, fear that substantial justice cannot be achieved in the foreign jurisdiction - would be replicated. Moreover, problems with the enforcement of these judgments in the foreign jurisdiction would continue. ${ }^{68}$ Notwithstanding these ongoing challenges, it is important to note the signalling function of these cases and the claim to jurisdiction made by the English courts under these circumstances, and the rejection of the legal fiction of the corporate veil.

The ongoing aftermath of the Vedanta case also shows the complexity of identifying victories and losses in environmental litigation; while the jurisdictional question was decided in favour of the claimants, the disproportionate costs and duration of the proceedings - four years and 9,300 documents - as well as the likely seizure of the Zambian subsidiary's assets by the Zambian government, ${ }^{69}$ may make this something of a Pyrrhic victory for the claimants. Bouwer's contribution also speaks to these questions of victory and defeat in environmental cases, and specifically the costs and benefits associated with large-scale private law climate litigation. ${ }^{70}$

Kim Bouwer's argument is structured around the holy grail metaphor, through which she discusses the role that high-profile private law climate litigation cases can play in the development of climate litigation. ${ }^{71}$ Specifically, she reflects on what the holy grail metaphor can tell us regarding the aims, impact and meaning of large private actions for damages within climate litigation, ${ }^{72}$ in light of the fact that these cases are often considered the 'holy grail' of climate change litigation. ${ }^{73}$ There are four main ways in which Bouwer believes the holy grail metaphor to have relevance for this area of private law. Firstly, the definition of victory and defeat is not always clear; secondly, the clarity of the quest (i.e., knowing what the holy grail is) is an essential precondition for a successful quest; thirdly, the quest necessarily entails an opportunity cost to the participants, regardless of potential success; and fourthly, the metaphor presents a possibility for reflection through narrative. ${ }^{74}$

With regard to private law climate litigation Bouwer elegantly shows how, despite its holy grail status, it is not entirely clear how private law litigation would offer a 'magic bullet' solution to climate change. ${ }^{75}$ However, by constructing this narrative through the most high-profile cases, including many 'unsuccessful' cases, a pattern of gradual

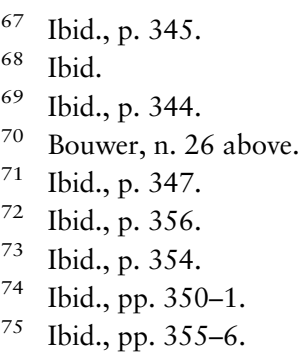


learning emerges that helps those on the 'quest' to better define their holy grail. Within this narrative, the initial Urgenda judgment is referenced as an important first victory, despite being relatively conservative in its ambition and outcome, compared with earlier cases within the climate litigation tradition. ${ }^{76}$ The fact that these earlier cases drew on the compensatory function of private law, and specifically compensation by the defendant rather than a public compensation scheme, would have imposed a level of responsibility on private actors that is absent from the Urgenda narrative. ${ }^{77}$ Unlike Urgenda, however, these cases were ultimately unsuccessful, meaning that their potential game-changing role was left unfulfilled. ${ }^{78}$ That said, a next generation of these cases is currently before the (predominantly US) courts, though here also success remains an aspiration. $^{79}$

This more nuanced view of victory and defeat is accompanied by a discussion of the complicated third-party effects that private law litigation can have. ${ }^{80}$ There is a clear desire for litigation with regard to climate (in)action, which arguably relates to a moral need to hold private actors accountable for past and future damage. The difficulty of doing so through litigation stems from the challenge of incorporating societal considerations, costs and benefits into litigation between two parties in the context of one specific case. Bouwer concludes that these difficulties make it hard to say whether the net benefit of these cases is positive or negative, ${ }^{81}$ underscoring the importance of the legal process in addition to legal outcomes. More generally, Bouwer's reflections aim to raise normative questions about the implications and meaning of these cases, which she believes are issues that occupy an important space within legal scholarship that empirical studies cannot and do not aim to fill. ${ }^{82}$

\section{CONCLUSION}

The events over the first few months of 2020 have cast doubt on many perceived certainties related to societal relationships, professional and private life, and the shape of the future. The deadly pandemic responsible for these uncertainties has created widescale human suffering, with effects that will be felt for some time. The tireless work of medical professionals and other related professionals is central to mitigating the effects of this crisis. As environmental scholars, with various skills, our work can help in contributing to new visions of the future with changing behaviour and changing impacts on nature. As transnational scholars, our work can be a reminder of the need to continue to collaborate, even at times where borders are closing and global supply chains are strained. Throughout our (scholarly) community the first response

\footnotetext{
76 Ibid., p. 368.

77 Ibid., p. 370.

78 Ibid.

79 Ibid., p. 373.

80 Ibid., p. 375.

81 Ibid., p. 378.

82 Ibid., p. 360.
} 
has been primarily one of support, hope, and resilience - bringing out the best in people at the worst of times. A good starting point for new visions for the future.

Editors-in-Chief

Thijs Etty

Veerle Heyvaert

Editors

Cinnamon Carlarne

Bruce Huber

Jacqueline Peel

Josephine van Zeben 